\title{
PERAN BIMBINGAN DAN KONSELING BELAJAR DALAM MENINGKATKAN MOTIVASI BELAJAR MATEMATIKA PADA PESERTA DIDIK KELAS VII-8 SMPN 3 PALANGKARAYA TAHUN PELAJARAN 2014/2015
}

\author{
ESTY ARYANI SAFITHRY \\ Dosen Program Studi Bimbingan dan Konseling Fakultas Keguruan dan Ilmu Pendidikan \\ Universitas Muhammadiyah Palangkaraya
}

\begin{abstract}
This study aimed to describe the role of guidance and counseling in motivating students to learn mathematics in class VII-8 SMP 3 Palangkaraya and describe the teacher's role in motivating students in learning.

This type of approach used in this study is a qualitative approach, namely with information, correc fact and reliable. Subjects in this study were the teacher in class VII-8. The data used is primary data and secondary data collection techniques used in data observation, interviews, and documentation. Analysis using the technique proposed by Milles and Hubermen namely data reduction, data display, and verification of decision making.

These results indicate that $B K$ teacher acts as a motivator and as a mentor in terms of motivating learners to learn math at grade VII-8 SMP 3 Palangkaraya.
\end{abstract}

Keywords : motivate learning by motivating learning

\section{ABSTRAK}

Penelitian ini bertujuan untuk mendeskripsikan tentang peran bimbingan dan konseling belajar dalam meningkatkan motivasi belajar matematika pada peserta didik kelas VII-8 SMPN 3 Palangka Raya dan mendeskripsikan tentang peran guru BK dalam memotivasi peserta didik dalam belajar.

Jenis pendekatan penelitian yang digunakan adalah pendekatan kualitatif, yaitu dengan informasi, fakta-fakta yang benar dan dapat dipertanggung jawabkan. Subjek dalam penelitian ini adalah guru BK kelas VII-8. Data yang digunakan adalah data primer dan data sekunder dengan teknik pengumpulan datanya menggunakan observasi, wawancara, dan dokumentasi. Teknik analisis data menggunakan teknik yang dikemukakan oleh Milles dan Hubermen yaitu reduksi data, display data, mengambil keputusan dan verifikasi.

Hasil penelitian ini menunjukan bahwa guru BK berperan sebagai motivator dan sebagai pembimbing dalam hal memotivasi belajar matematika pada peserta didik kelas VII-8 SMPN 3 Palangkaraya.

Kata kunci : peran bimbingan dan konseling belajar

\section{PENDAHULUAN}

Sekolah sebagai suatu sistem yang terdiri atas beberapa komponen, yakni guru, tata usaha, peserta didik, sarana dan prasarana lainnya yang menunjang pembelajaran guna tercapainya tujuan pendidikan nasioanal sebagaimana yang digaris di dalam Undang-Undang Nomor 20 tahun 2003 (Pahay W. Jimat, 2008:2) yaitu : Untuk berkembangan potensi peserta didik agar menjadi manusia yang beriman dan bertakwa kepada Tuhan Yang Maha Esa, berakhlak mulia, sehat, berilmu, cakap, kreatif, mandiri, dan menjadi warga Negara yang demokrasi serta bertanggung jawab

Untuk mencapai tujuan tersebut, maka salah satu program pendidikan di sekolah yang ikut menentukan keberhasilan pendidikan yaitu program pelaksanaan layanan bimbingan dan 
konseling. Menurut pendapat Audi Mapiare (Pahay W. Jimat, 2008:2) bahwa Bimbingan dapat diartikan sebagai proses pemberian bantuan yang dilakukan secara sistematis, metodis, dan demokratis dari seseorang yang memiliki kompetensi yang memadai dalam menerapkan pendekatan, metode dan teknik layanan kepada induvidu agar lebih memahami, menerima diri, mengarahkan diri dan memiliki kemampuan nyata dari dalam mencapai penyesuaian, membuat pilihan dan memecahkan persoalan-persoalan secara lebih memadai sesuai tingkat perkembangan yang dicapainya. Kesemuannya itu, ditujukan untuk mencapai kesejahteraan mental dan kebahagiaan yang bermanfaat bagi diri dan lingkungan.

Untuk meningkatkan motivasi belajar pada peserta didik tidak hanya terletak pada guru mata pelajaran dan orang tua saja, melainkan merupakan tanggung jawab bersama agar proses pembelajaran yang terjadi pada diri anak berjalan dengan baik dan prestasi belajarnya maksimal. Salah satu petugas yang sangat berperan dalam meningkatkan motivasi belajar peserta didik adalah guru bimbingan dan konseling yang ada dimasing-masing sekolah. Hal ini sesuai dengan pendapat H. Koestoer Partowisastro (Pahay W. Jimat, 2008:3) bahwa Petugas bimbingan dalam tugas-tugas bimbinganya merupakan komplemen dan bagian integral dalam usaha-usaha untuk mencapai tujuan pendidikan, maka para pendidik dan para petugas bimbingan perlu dilengkapi dengan pengetahuan, sikap dan keterampilan dalam hubungannya dengan mengatasi kesulitan belajar para peserta didik.
Matematika merupakan ilmu universal yang mendasari perkembangan teknologi modern, mempunyai peranan penting dalam berbagai disiplin ilmu dan memajukan daya pikir manusia. Perkembangan pesat di bidang teknologi informasi dan komunikasi dewasa ini didasari oleh perkembangan matematika di bidang teori bilangan, aljabar, analisis, teori peluang dan matematika diskrit. Untuk menguasai dan menciptakan teknologi di masa depan diperlukan penguasaan matematika yang kuat.

Namun dalam proses belajar mengajar di kelas, pelajaran matematika dianggap sulit, tidak menarik dan membosankan bagi siswa pada umumnya, motivasi belajar siswa menjadi rendah dan hasil belajarnyapun juga rendah, hal ini tercermin dari masih minimnya perolehan nilai matematika dalam ulangan kompetensi dasar baik dalam ulangan per Kompetensi Dasar (KD), ulangan blok maupun Ujian Akhir Nasional (UAN).

Hasil angket motivasi awal siswa serta data hasil tes skolastik yang dilakukan oleh pihak sekolah setiap penerimaan siswa baru menunjukkan bahwa rendahnya hasil belajar siswa bukan karena kurangnya intelegensi yang dimiliki oleh siswa tetapi karena sangat sedikit siswa yang termotivasi untuk belajar matematika

Dalam kaitannya dengan masalah rendahnya motivasi belajar yang terjadi pada sejumlah siswa kelas VII-8 SMPN 3, maka guru mengadakan kegiatan bimbingan kelompok agar siswa dapat lebih bersemangat dalam belajar, dalam mengatasi siswa yang motivasi belajarnya rendah perlu pendekatan yang tepat, siswa SMP yang motivasi belajarnya rendah karena memiliki perilaku yang kurang baik yakni memiliki kebiasaan-kebiasaan 
negatif seperti malas belajar, malas mengerjakan tugas atau PR, ramai di kelas, membolos dan lain-lain, sehingga model pendekatan konseling yang digunakan haruslah yang bisa menghilangkan perilaku kurang baik ersebut yaitu model konseling behavioral karena tujuan konseling behavioral.

Berdasarkan uraian diatas maka perlu adanya upaya untuk meningkatkanmotivasi belajar siswa SMP, salah satu alternatif layanan bisa melalui layanan bimbingan belajar, sedang pendekatan konselingnya bisa menggunakan model pendekatan konseling behavioral.

Berdasarkan permasalahan di atas melalui penelitian ini diharapkan guru mampu memainkan peran sebagai inovator pembelajaran. Seorang guru harus mampu menggunakan metode pembelajaran yang tepat sehingga dapat memudahkan serta dapat mengubah image siswa yang keliru terhadap matematika, yang pada akhirnya matematika menjadi pelajaran yang mudah, menarik serta menyenangkan bagi semua peserta didik.

Berdasarkan uraian tersebut di atas, maka penelitian ini akan berusaha mengkaji Peran Bimbingan Dan Konseling Belajar Dalam Meningkatkan Motivasi Belajar Matematika Pada Peserta Didik Kelas VIII-8 SMPN 3 Palangkaraya Tahun Pelajaran 2014/2015.

\section{METODE PENELITIAN}

\section{Metode dan Prosedur Penelitian}

Berdasarkan pada permasalahan dan tujuan pada penelitian ini, dalam pelaksanaannya peneliti menggunakan metode kualitatif. Sedangkan untuk mengungkapkan masalah dalam penelitian ini. Peneliti menggunakan jenis penelitian studi kasus. Dengan adanya studi kasus ini dimaksudkan untuk menyajikan analisa permasalahan secara detail, terutama dalam menganalisa peran bimbingan konseling belajar dalam memotivasi belajar matematika pada peserta didik kelas VII-8 SMP N 3 Palangka Raya.

\section{Data dan Sumber Data Penelitian}

1. Data

a. Peran guru bimbingan dan konseling

b. Peserta didik kelas VII-8 SMPN 3 Palangka Raya.

2. Sumber Data Penelitian

a. Sumber Data Primer

Dalam data primer ini, peneliti langsung bertatap muka dengan para subjek penelitian dalam mengumpulkan data, dimana menggunakan observasi dan wawancara langsung dengan guru bimbingan dan konseling dan peserta didik kelas VII-8 guna memperoleh data serta informasi yang akurat mengenai peran bimbingan dan konseling belajar dalam memotivasi belajar matematika peserta didik kelas VII-8 SMPN 3 Palangka Raya.

b. Sumber Data Sekunder Data sekunder dalam penelitian ini adalah hasil wawancara dengan guru BK dan peserta didik kelas VII-8 mengenai peran bimbingan dan konseling belajar dalam memotivasi belajar matematika. 


\section{Teknik Dan Prosedur Pengumpulan Data}

\section{Prosedur Pengumpulan Data Observasi}

Dalam penelitian ini, peneliti menggunakan teknik partisipatif dimana peneliti terjun langsung kelapangan untuk melihat dan mengamati situasi dan kondisi dilapangan terkait mengenai peran bimbingan dan konseling belajar dalam memotivasi belajar matematika peserta didik kelas VII-8 SMPN 3 Palangka Raya. Observasi partisipatif pasif ini digunakan untuk mengamati terkaitan dengan peran guru BK dalam meningkatkan motivasi belajar matematika pada peserta didik kelas VII-8.

\section{Wawancara}

Pada penelitian ini peneliti wawancarai tentang peran guru bimbingan dan konseling dalam memotivasi belajar matematika pada peserta didik kelas VII-8 SMPN 3 Palangka Raya, penelitian ini menggunakan metode wawancara terstruktur. Dengan wawancara ini diharapkan proses tanya jawab itu dapat berlangsung dan terarah, untuk mengumpulkan data-data yang relevan. Dalam pelaksanaannya peneliti menggunakan pedoman wawancara terstruktur dan yang diwawancarai yaitu :

1) Guru bimbingan dan konseling

2) 3 Peserta didik kelas VII-8 SMPN 3 Palangka Raya.

\section{Dokumentasi}

Dalam penelitian ini, pengumpulan data juga diperoleh dokumentasi yang menunjang kegiatan penelitian berupa program bimbingan dan konseling, dan rencana pelaksanaan pelayanan bimbingan dan konseling (RPPBK).
1) Perekaman Data

Dalam proses pengumpulan data, tentunya diperlukan alat bantu yang dapat menunjang kegiatan tersebut, karena mengingat peneliti sangat terbatas karena adanya alat bantu yang digunakan. Adapun alat bantu yang digunakan dalam penelitian ini yaitu sebagai berikut :

a) Buku catatan untuk mencatat semua percakapan serta hal-hal yang dianggap penting.

b) Dengan bantuan alat perekam yaitu handphone, cara ini cukup sempurna, dimana semua pembicaraan yang telah berlangsung dapat terungkap kembali, selain itu wawancara juga akan berkembang dengan baik.

\section{Prosedur Pengumpulan Data}

Data mentah yang dikumpulkan oleh peneliti dilapangan akan ada gunanya setelah dianalisis. Analisis dalam penelitian merupakan hal yang penting, karena dengan analisis inilah data yang akan nampak manfaatnya. Terutama dalam memecahkan masalah penelitian dan mencapai tujuan akhir penelitian. Dalam analisis, dipisahkan antara data yang relevan dengan data yang kurang terkaitan.

\section{Data Reduction (Reduksi Data)}

Dalam mereduksi data, setiap peneliti akan dipandu oleh tujuan yang akan dicapai. Tujuan utama dari penelitian kualitatif adalah menemukan segala sesuatu yang dipandang asing, tidak dikenal, belum memiliki pola, justru itulah yang harus dijadikan perhatian peneliti dalam melakukan reduksi data. 


\section{Data Display (Penyajian Data)}

Setelah data direduksi, maka langkah selanjutnya adalah mendisplaykan data atau penyajian data. Display data yaitu penyusunan informasi yang akan memungkinkan peneliti untuk membuat suatu kesimpulan dan pengambilan keputusan.

3. Conclusioan Drawing/Verification (Penarikan Kesimpulan)

Tahap pengambilan keputusan dan verifikasi merupakan upaya peneliti untuk mencari makna dari hasil analisis data. Dalam hal ini, verifikasi data dilakukan dari awal penelitian sampai akhir penelitian sehingga pengambilan kesimpulan dapat diambil dengan tepat.

\section{Pemeriksaan Keabsahan Data}

Pengecekan keabsahan data dalam penelitian ini, dapat dilakukan dengan cara sebagai berikut :

1. Kredibilitas

Untuk mengetahui tingkat kreadibilitas dalam hal penelitian ini, tahap pertama yang dilakukan oleh peneliti yakni triangulasi data dan informasi yang telah diperoleh. sebab dikhawatirkan jika hanya menggunakan satu sumber hasil yang diperoleh tidak optimal. Teknik triangulasi lebih mengutamakan efektivitas proses dan metode yang diinginkan

2. Transferabilities

Pentingnya transferabilities ini, yaitu untuk mengetahui bagaimana upaya guru BK dalam memotivasi belajar matematika pada peserta didik.

3. Dependabilities

Dalam dependabilities ini, peneliti mencari dan mengumpulkan data secara empiris tentang masalah yang akan diteliti. Penelitian ini, peneliti melakukan tahapan awal yaitu melakukan observasi untuk mengetahui kondisi, objek, serta subjek yang akan diteliti. Setelah peneliti mendapatkan informasi melalui observasi, maka selanjutnya peneliti melanjutkan dengan wawancara langsung pada objek yang jadi sasaran penelitian.

4. Konfirmabilitas

Untuk mendapatkan konfirmabitas serta keabsahan data dalam penelitian ini, peneliti menggunakan beberapa teknik, yaitu dengan observasi, wawancara, dan dokumentasi serta data-data dari guru bimbingan dan konseling mengenai layanan bimbingan dan konseling di sekolah tersebut.

\section{HASIL DAN PEMBAHASAN}

Dalam penelitian mengenai peran bimbingan dan konseling belajar dalam meningkatkan motivasi belajar matematika pada peserta didik, peneliti melaksanakan penelitian ini kurang lebih dua bulan dari tanggal 03 Oktober sampai 03 Desember 2014.

\section{Peran Konselor Dalam Bimbingan dan Konseling Belajar}

Guru BK di SMPN 3 Palangka Raya memiliki posisi yang masih belum dianggap sangat penting dalam komponen pendidikan karena tidak memiliki jadwal atau jam khusus untuk masuk kelas memberikan layanan kepada peserta didik. Disamping itu, guru BK juga tidak terlalu mengenal peserta didik dengan baik dan peserta didik juga tidak terlalu mengenal akan sosok guru BK itu sendiri. Dari dokumen yang diperoleh peneliti dari guru BK yang bersangkutan juga menunjukan bahwa ruangan yang diberikan oleh 
SMPN 3 kepada guru BK untuk melaksanakan tugasnya sudah cukup baik, karena ketersediaan ruangan khusus untuk bimbingan dan konseling merupakan faktor pendukung untuk mengadakan penyelenggaran bimbingan dan konseling secara khusus. Dengan demikian ruangan khusus tersebut guru BK dapat menjalankan tugasnya dengan nyaman dan peserta didik juga akan merasa lebih nyaman.

Guru BK berusaha untuk mengetahui akan kebutuhan-kebutuhan yang dibutuhkan peserta didiknya salah satunya memotivasi dalam belajar matematika. Dengan mengetahuinya guru BK berharap dapat memenuhinya sehingga peserta didik menjadi senang karena kebutuhannya telah dipenuhi. Dilihat dari keadaan yang ada di SMPN 3 Palangka Raya dan dari pengamatan peneliti di lapangan terlihat bahwa antara peserta didik dan guru BK memiliki hubungan yang baik.

Peserta didik merasa bahwa kebutuhannya terpenuhi, sehingga mereka menujukkan kegairahannya dalam mengikuti proses belajar khususnya amta pelajaran emtematika dengan baik. Peneliti melihat ini sebagai langkah awal yang baik dalam rangka usaha guru BK menggairahkan peserta didiknya agar semakin termotivasi dalam meningkatkan hasil belajarnya.

Dari hasil wawancara peneliti menyimpulkan bahwa guru BK telah melaksanakan tugasnya dengan baik dengan cara memberi motivasi belajar matematika yang realistis kepada peserta didiknya. Dengan adanya usaha dari guru BK untuk memotivasi belajar matematika peserta didik dalam belajar maka diharapkan peserta didik dapat termotivasi dalam belajar dan nilai matematika dapat meningkat.
Guru BK memotivasi belajar metematika peserta didiknya bukan harus memberikan hadiah seperti benda. Guru BK di SMPN 3 Palangka Raya memiliki cara sendiri dalam memberikan penghargaan kepada peserta didik dengan cara memberikan dorongan dan pujian kepada peserta didiknya agar dapat selalu termotivasi dalam belajar.

\section{Pembahasan}

Peran guru BK dalam bimbingan dan konseling belajar untuk meningkatkan motivasi belajar matematika sudah berjalan dengan baik walaupun masih banyak kekurangankekurangannya, sesuai dengan pernyataan guru BK bahwa selama ini guru BK sudah berusaha selalu memberikan motivasi belajar kepada peserta didik. Dari pernyataan tersebut guru BK sudah jelas bahwa pelaksanaan bimbingan dan konseling belajar sudah belajar dengan baik karena bimbingan dan konseling belajar merupakan bagian penting dari pada tugas dan tanggung jawabnya sebagai guru BK.

Apabila melihat dari unjuk kerja guru BK di SMPN 3 Palangka Raya maka dapat dikatakan guru BK tersebut telah memenuhi kewajibannya dalam mengembangkan tanggung jawabnya tersebut. Dimana guru BK telah menyusun program pelaksanaan bimbingan dan konseling yang menyesuaikan dari pada kebutuhankebutuhan peserta didiknya salah satunya adalah motivasi yang rendah dalam nbelajar matematika.. Penyusunan tersebut merupakan tugas dan tanggung jawab dari guru BK, seperti yang diungkapkan oleh Gysbers,N.C. \& P. Henderson ( Depdiknas, 2008 : 40) yang 
menyatakan bahwa seorang konselor harus mampu :

a. merancang kegiatan pelayanan bimbingan dan konseling

b. mengimplementasikan kegiatan pelayanan bimbingan dan konseling

c. menilai proses dan hasil kegiatan pelayanan bimbingan dan konseling serta melakukan penyesuaian-penyesuaian sambil jalan (midcourse adjustments) berdasarkan keputusan transaksional selama rentang proses bimbingan dan konseling dalam rangka memandirikan konseli (mind competence).

Selain itu, pernyataan program itu merupakan kewajiban bagi guru BK sebagaimana pendapat yang diungkapkan oleh Junaedi \& Hadi (2013) bahwa :

Dalam BK, seorang konselor dituntut untuk membuat program BK. Sehingga kegiatan yang ingin dilakukan berjalan dengan lancar. Program tersebut mencakup pemberian layanan BK oleh konselor terhadap siswa.

Kegiatan melalui kontak langsung dengan siswa diperlukan waktu tersendiri, dengan catatan siswa tidak boleh dirugikan dalam kegiatan belajarnya dengan guru mata pelajaran/guru praktik. Untuk ini perlu dialokasikan waktu tersendiri minimum satu jam dan maksimal dua jam pelajaran satu minggu perkelas, jam pelajaran yang tersediakan itu disediakan untuk antara lain melaksanakan : layanan pembelajaran klasikal, layanan penempatan/penyaluran klasikal, evaluasi klasikal kegiatan bimbingan dan konseling minggu sebelumnya serta perencanaan kegiatan minggu berikutnya kegiatan aplikasi instrumentasi, layanan informasi klasikal.
Kutipan mengenai pernyataan tersebut menegaskan bahwa pelayanan bimbingan dan konseling memerlukan waktu yang cukup agar seorang guru BK dapat bertatap muka secara langsung dengan peserta didiknya.

Berdasarkan dari pernyataan guru BK dan dari pengamatan peneliti serta dokumen yang peneliti peroleh jelas terlihat bahwa di SMPN 3 Palangka Raya telah tersedia ruang khusus untuk bimbingan dan konseling bagi guru BK.

Pendapat mengenai sarana pelaksanaan bimbingan dan konseling oleh guru BK dapat dilihat dari pernyataan yang dikemukan oleh Depdiknas (2008 :238) menyatakan bahwa Ruang bimbingan dan konseling merupakan salah satu sarana penting yang turut mempengaruhi keberhasilan pelayanan bimbingan dan konseling di sekolah. Dengan memperhatikan prinsip-prinsip perlu mempertimbangkan letak atau lokasi, ukuran, jenis dan jumlah ruangan, serta berbagai fasilitas pendukung lainnya.

Selain ruang yang khusus, tentunya tanggung jawab guru BK dalam membimbing peserta didik yang dilayani juga memilki batasanbatasan jumlah peserta didik yang harus dilayani. berdasarkan hasil wawancara dengan guru BK dan dokumen yang peneliti peroleh bahwa di SMPN 3 Palangka Raya memiliki peserta didik lebih dari 800 peserta didik, akan tetapi memiliki 6 orang guru BK yang harus membimbing semua peserta didik tersebut.

Keadaan tersebut selaras denga pendapat yang dikemukan oleh ABKIN (2011 : 3) menyatakan bahwa Guru BK/konselor harus bertanggung jawab dalam memberikan pelayanan setidaknya bagi 150 orang peserta didik dan tidak boleh lebih dari 250 peserta didik setiap tahunnya. 
Guru BK/konselor yang diberi tugas tambahan sebagai kepala sekolah mengampu minimal 40 orang peserta didik dan wakil kepala sekolah minimal 80 orang peserta didik yang menjadi kewajibannya dalam pelayanan BK. Konselor harus bekerja 24 jam per minggu dengan peserta didik. pernyataan tersebut menyatakan bahwa setiap satu orang guru BK hanya bertanggung jawab mangampu 150 orang peserta didik saja atau setidaknya tidak lebi8h dari 250 orang peserta didik. Apabila dikaitkan anatar pendapat tersebut dengan yang terjadi di SMPN 3 Palangka Raya dapat dikatakan keduanya selaras atau sebanding.

\section{KESIMPULAN DAN SARAN}

\section{Kesimpulan}

1. Guru bimbingan dan konseling berperan sebagai motivator dalam memotivasi belajar matematika pada peserta didik dengan cara memberikan penghargaan berupa pujian, dorongan dan semangat kepada peserta didik sehingga peserta didik termotivasi dalam belajar matematika.

2. Guru bimbingan dan konseling sebagai pembimbing yang selalu mengarahkan tingkah laku peserta didik, dengan cara menunjukkan pada peserta didik hal-hal yang dilakukan tidak benar dan meminta pada mereka untuk melakukan kembali dengan benar dan sebaik-baiknya.

Dari kesimpulan diatas maka guru bimbingan dan konseling berperan sebagai motivator dan sebagai pembimbing dalam hal memotivasi belajar matematika pada peserta didik kelas VII-8 SMPN 3 Palangka Raya.

\section{Saran}

Berdasarkan hasil dari penelitian yang telah dilakukan, peneliti menyampaikan beberapa saran :

\section{Saran Teoretis}

Bagi mahasiswa maupun pihak lain yang tertarik ingin mengkaji lebih jauh mengenai peran bimbingan dan konseling belajar dalam meningkatkan hasil belajar peserta didik, diharapkan hasil penelitian ini dapat menambah kajian ilmiah pendidikan dan dapat menjadi bahan referensi bagi pengembangan penelitian selanjutnya.

\section{Saran Praktis}

a. Bagi kepala sekolah diharapkan dapat lebih memperhatikan kelengkapan yang diperlukan guru BK seperti jadwal/jam masuk kelas bagi guru BK karena dengan adanya jadwal/jam masuk kelas guru BK akan lebih akrab dengan peserta didiknya dan proses layanan bimbingan dan konseling akan berjalan dengan baik sebagaimana mestinya.

b. Bagi guru BK diharapkan dapat lebih memperhatikan peserta didiknya dan memberikan layanan bimbingan dan konseling yang lebih insentif bagi peserta didik yang sedang mengalami masalah terutama masalah belajar agar diadakan bimbingan dan konseling belajar secara khusus.

c. Bagi peserta didik yang merasa sedang menghadapi masalah terutama masalah belajar agar mau menyampaikan apa yang menjadi permasalahannya kepada guru BK agar dapat dicari jalan keluar yang tepat untuk permasalahan yang dialami. 


\section{DAFTAR PUSTAKA}

ABKIN. 2011. Panduan Pelayanan Bimbingan Karir Bagi Guru Bimbingan Konseling/Konselor Pada Satuan Dasar dan Menengah. Jakarta. ILO

Ahmad Zaini Dahlan. 2011.Perbedaan Hasil Belajar Matematika Antara Penerapan Pendekatan Personal dan Pendekatan Deduktif Pada Peserta Didik Kelas III SDN-9 Menteng Palangka Raya

Burhan Bungin. 2010. Analisis Penelitian Kualitatif. Jakarta : Rajawali Pers.

Departemen Pendidikan Nasional. 2008. Bimbingan dan Konseling di Sekolah. Jakarta. Balai Pustaka. Tim Penulis

Dewa Ketut Sukardi. 2000. Bimbingan dan Konseling Di Sekolah. Jakarta : PT.Rineka Cipta.

Erika Kusumawardani. 2012. Hambatan Peserta Didik Mengerjakan Pekerjaan Rumah.

Junaedi \& Hadi Warsito, W. 2013. Hubungan Antara Persepsi Siswa Terhadap Kompetensi Kepribadian dan Kinerja Konselor dengan Minat Siswa untuk Memamfaatkan Layanan Bimbingan dan Konseling. Anterior jurnal.

Latipun. 2008. Psikologi Konseling. Malang UMM Press.

Pahay W. Jimat. 2008. Studi Tentang Peranan Guru Bimbingan dan Konseling Dalam Membantu Mengatasi Kesulitan Belajar SMA Muhammadiyah Palangka Raya.

Pupuh Fathurrohman dan M.Sobry Sutikno. 2007. Strategi Belajar Mengajar. Bandung : Refika Aditama.

Sardiman,A.M. 2003. Interaksi dan Motivasi Belajar Mengajar. Jakarta : Rajawali Pers.

Slameto. 2010. Belajar dan Faktor-Faktor Yang Mempengaruhi. Jakarta : Rineka Cipta.
Roslan Rosady. 2008. Metode Penelitian Public Relation Dan Komunikasi. Jakarta : PT Raja Grapindo Persada.

Sofyan S. Willis. 2004. Konseling Induvidual Teori Dan Praktik. Bandung. Alfabeta cv.

Sumadi Suryabrata. 2010. Metode Penelitian. Jakarta : Rajawali Pers.

Supardi. 2003. Korelasi Antara Layanan Bimbingan Belajar Dengan Hasil Belajar Peserta Didik SLTPN 5 Selat Kuala Kapuas.

Sugiyono. 2009. Metode Penelitian Kuantitatif Kualitatif dan R\&D.Bandung : Alfabeta

Syafaruddin \& Nasution, I. 2005. Manajemen Pembelajaran. Jakarta. Quantum Teaching.

Winkel,W.S. 2004. Bimbingan Dan Konseling Di Institusi Pendidikan. Jakarta : Gramedia 